\title{
Analisis Kendali Mutu Ekspor Buah Manggis dengan Menggunakan Statistical Quality Control (SQC) pada Eksportir PT. X
}

\author{
Friska Anzalni Julian*
}

Prodi Matematika, Fakultas Matematika dan Ilmu Pengetahuan Alam, Universitas Islam Bandung, Indonesia.

*friskaanzalnij@gmail.com

\begin{abstract}
Mangosteen fruit export is one of the fresh fruit export commodities from the agricultural sector which contributes to the country's foreign exchange. The increase in the country's foreign exchange is influenced by the increasing volume of mangosteen exports, so there needs to be special handling related to the quality of the mangosteen fruit to be exported. Analysis of the quality control of mangosteen exports can be done using Statistical Quality Control (SQC). Quality control analysis using SQC begins with forming a flowchart to review the flow and processes that will be carried out, then to make it easier to show and understand the data, check sheets and histograms are arranged. Based on the results of the analysis using the control chart $\mathrm{p}$ which shows that the damage that occurs is still outside the control limits at several intervals with an upper control limit of 0.068 . The Pareto diagram shows that the most dominant damage was found in the size mismatch of the mangosteen fruit, which was $8197.5 \mathrm{~kg}$ or $90.152 \%$ of the damage. Based on the scatter diagram, it is known that there is a very strong relationship, indicated by a correlation of 0.934 between the size discrepancy and the damage that occurs, while the discrepancy in the maturity level of the mangosteen shows a low correlation with a correlation of 0.305 . This means that the size discrepancy has a very strong impact and the maturity level discrepancy has a low impact on the damage that occurs. In addition, by using a causal diagram, it is known that the factors that cause damage to the mangosteen fruit are caused by environmental factors and human factors.
\end{abstract}

Keywords: Quality Control, Export, Mangosteen, Control Chart, Statistical Quality Control (SQC).

Abstrak. Ekspor buah manggis menjadi salah satu komoditas ekspor buah segar dari sektor pertanian yang memiliki kontribusi terhadap devisa negara. Peningkatan devisa negara dipengaruhi oleh meningkatnya volume ekspor buah manggis, sehingga perlu adanya penanganan khusus terkait mutu buah manggis yang akan di ekspor. Analisis kendali mutu ekspor buah manggis dapat dilakukan dengan menggunakan Statistical Quality Control (SQC). Analisis kendali mutu dengan menggunakan SQC diawali dengan membentuk flowchart untuk meninjau alur dan proses yang akan dilakukan, selanjutnya untuk memudahkan dalam menunjukkan dan memahami data disusun check sheet dan histogram. Berdasarkan hasil analisis dengan menggunakan peta kendali $\boldsymbol{p}$ yang menunjukkan bahwa kerusakan yang terjadi masih diluar batas kendali dibeberapa interval dengan batas kendali atas sebesar 0,068. Diagram pareto menunjukkan kerusakan yang paling dominan terdapat pada ketidaksesuaian ukuran buah manggis yaitu sebanyak $8197.5 \mathrm{~kg}$ atau $90,152 \%$ dari kerusakan yang terjadi. Berdasarkan diagram sebar diketahui terdapat hubungan yang sangat kuat ditunjukkan oleh korelasi sebesar 0.934 antara ketidaksesuaian ukuran terhadap kerusakan yang terjadi, sedangkan ketidaksesuaian tingkat kematangan buah manggis menunjukkan hubungan yang rendah dengan korelasi sebesar 0.305 . Hal tersebut berarti ketidaksesuaian ukuran memberikan dampak yang sangat kuat dan ketidaksesuaian tingkat kematangan memberikan dampak yang rendah terhadap kerusakan yang terjadi. Selain itu, dengan menggunakan diagram sebab-akibat diketahui faktor penyebab kerusakan yang terjadi pada buah manggis disebabkan oleh faktor lingkungan dan faktor manusia.

Kata Kunci: Kendali Mutu, Ekspor, Manggis, Peta Kendali, Statistical Quality Control (SQC). 


\section{A. Pendahuluan}

Ekspor merupakan kegiatan mengeluarkan barang atau jasa dari suatu negara ke berbagai negara lain. Ekspor yang telah dilakukan oleh Indonesia terdapat pada berbagai bidang, salah satunya pada bidang pertanian. Sebagai contoh ekspor yang dilakukan pada bidang pertanian yaitu ekspor buah manggis. Kementrian Pertanian Republik Indonesia mencatat bahwa volume ekspor buah manggis tertinggi pada periode tahun 2012-2018 terjadi pada tahun 2018 dengan volume ekspor tertinggi mencapai 38.831ton yang memiliki kontribusi terhadap devisa negara Indonesia senilai US\$33.270.000. Kondisi tersebut perlu dipertahankan dan terus ditingkatkan oleh Indonesia, dengan cara meningkatkan produksi buah manggis beriringan dengan menjaga mutu buah manggis yang akan diekspor.

Buah manggis menjadi salah satu komoditas ekspor yang dapat bersaing di pasar internasional sebagai komoditas ekspor buah segar yang dapat dimanfaatkan mulai dari buah hingga kulitnya. Menurut penelitian yang telah dilakukan dalam buah manggis terdapat senyawa atau zat yang bermanfaat bagi kesehatan. Selain kandungan senyawa dan manfaat yang dimiliki buah manggis, buah manggis juga menjadi salah satu komoditas ekspor unggulan dari Indonesia sehingga memerlukan penanganan yang baik yang dapat dilakukan oleh eksportir.

Eksportir buah manggis tersebar dibeberapa wilayah di Indonesia. Salah satu eksportir buah manggis adalah PT. X, dimana PT. X merupakan eksportir buah dan sayur dengan jenis yang beragam. PT. X merupakan eksportir dengan buah dan sayur yang diekspor antara lain manggis, mangga, melon, ubi, salak, dan melati. Komoditas ekspor buah tertinggi di PT. X terdapat pada buah manggis. Dalam menjaga mutu dan daya saing ekspor buah manggis PT. X telah melakukan beberapa tahapan sebelum buah manggis tersebut diekspor salah satunya tahapan penyortiran.

Dalam melakukan penyortiran buah manggis terdapat beberapa hal yang diperhatikan seperti kulit, warna, ukuran, tingkat kematangan hingga kelopak yang ada pada buah manggis. Standar mutu dari buah manggis ditetapkan PT. X untuk menjaga daya saing pemasaran buah manggis di pasar internasional. Selain itu, tahapan penyortiran menjadi sangat penting karena tahapan penyortiran menjadi tahap awal dalam menentukan buah tersebut layak atau tidak untuk diekspor.

Pada tahap penyortiran buah manggis terdapat suatu kondisi dimana ditemukan buah manggis yang tidak memenuhi standar mutu yang ditetapkan PT. X. Ketidaksesuaian tersebut dapat dikatakan sebagai kerusakan atau cacat pada buah manggis yang tidak layak untuk ekspor. Ketidaksesuaian tersebut berupa ukuran buah manggis dan tingkat kematangannya tidak sesuai dengan standar mutu yang ditetapkan oleh PT. X. Ketidaksesuaian mutu tersebut menimbulkan suatu kondisi dimana perlunya analisis kendali mutu pada kerusakan atau cacat buah manggis yang di produksi. Selain itu, perlu diketahui pula penyebab kerusakan atau cacat yang terjadi pada buah manggis.

Analisis kendali mutu pada ekspor buah manggis di PT. X belum dilakukan, sehingga belum diketahui kerusakan atau cacat yang terjadi masih dalam batas kendali atau tidak. Analisis kendali mutu pada ekspor buah manggis dalam tahap penyortiran, secara analisis dapat dilakukan dengan menggunakan Statistical Quality Control (SQC).

Berdasarkan latar belakang yang telah diuraikan, maka perumusan masalah dalam penelitian ini sebagai berikut: "Bagaimana analisis kendali mutu ekspor buah manggis pada Eksportir PT. X dengan menggunakan Statistical Quality Control (SQC)?”. Selanjutnya, tujuan dalam penelitian ini adalah untuk mengetahui kerusakan atau cacat yang terjadi pada buah manggis masih dalam batas kendali atau tidak serta diketahui pula faktor penyebab kerusakan yang mempengaruhinya.

\section{B. Metodologi Penelitian}

Peneliti menggunakan metode Statistical Quality Control (SQC) dengan menggunakan pendekatan deskriptif kuantitatif. Data yang digunakan dalam penelitian ini merupakan data penyortiran buah manggis selama bulan Januari-Desember 2020 di PT. X

Data yang digunakan pada penelitian ini sebanyak 100 hari penyortiran atau 100 grup/sampel. Pada tahapan penyortiran buah manggis terdapat buah manggis yang lolos sortir 
dan tidak lolos sortir. Buah manggis yang layak untuk diekspor atau lolos sortir berarti telah memenuhi standar yang telah ditetapkan, sedangkan buah manggis dikatakan tidak lolos sortir karena tidak memenuhi standar yang ditetapkan oleh PT. X. Standar mutu yang ditetapkan seperti warna, kulit, ukuran, tingkat kematangan, dan jumlah kelopak pada buah manggis. Adapun klasifikasi kerusakan yang akan digunakan pada penelitian ini yaitu kerusakan berdasarkan ketidaksesuaian ukuran dan tingkat kematangan buah manggis.

Analisis kendali mutu ekspor buah manggis dilakukan setelah pengumpulan data yang diperoleh melalui wawancara. Selanjutnya dilakukan pengumpulan beberapa kajian pustaka sesuai dengan judul yang akan diteliti. Berdasarkan kajian pustaka yang telah dilakukan penyelesaian permasalahan dalam menganalisis kendali mutu pada ekspor buah manggis dapat dilakukan dengan menggunakan SQC. Analisis yang dilakukan dengan SQC menggunakan 7 alat bantu yaitu flowchart, lembar pemeriksaan (check sheet), histogram, peta kendali $\mathrm{p}$ ( $p$ chart), diagram pareto, diagram sebar (scatter diagram), dan diagram sebab-akibat (fishbone diagram).

\section{Hasil Penelitian dan Pembahasan}

\section{Flowchart}

Berikut adalah flowchart dari alur dan proses yang akan dilakukan dalam penelitian ini yang ditunjukkan oleh Gambar 1.

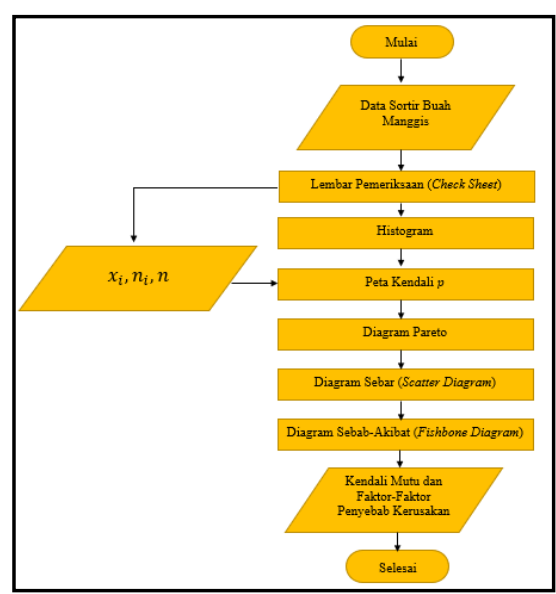

Gambar 1. Flowchart

Alur atau proses dimulai dari menginputkan data hasil sortir selanjutnya dibuat dalam bentuk tabel pada lembar pemeriksaan dan dari kerusakan yang ditemukan pada saat penyortiran dibentuk dalam histogram. Peta kendali $p$ digunakan untuk meninjau apakah kerusakan yang terjadi masih dalam batas kendali atau tidak berdasarkan data pada lembar pemeriksaan. Untuk mengetahui kerusakan yang paling dominan digunakan diagram pareto dan diagram sebar digunakan untuk melihat hubungan antara kerusakan yang terjadi terhadap buah manggis yang tidak lolos sortir. Adapun faktor penyebab dari kerusakan yang terjadi akan ditunjukkan dengan menggunakan diagram sebab-akibat. Hasil atau output pada penelitian ini berupa analisis kendali mutu pada ekspor buah manggis masih dalam batas kenali atau tidak dan faktor-faktor penyebab kerusakan yang mempengaruhinya. 
166 | Friska Anzalni Julian, et al.

\section{Lembar Pemeriksaan (Check Sheet)}

Tabel 1. Lembar Pemeriksaan (Check Sheet)

\begin{tabular}{|c|c|c|}
\hline \multicolumn{2}{|l|}{ Data Hasil Sortir } & Jumlah (KG) \\
\hline \multirow{3}{*}{ Lolos Sortir } & SP 1 & 366414 \\
\hline & SP 2 & 1264 \\
\hline & REST & 15460.5 \\
\hline \multirow{2}{*}{ Tidak Lolos Sortir } & PK & 8197.5 \\
\hline & BS & 895.5 \\
\hline Total & & 392231.5 \\
\hline
\end{tabular}

Sumber: Data diolah (2021)

Berdasarkan Tabel 1 diketahui bahwa buah manggis yang lolos sortir pada bulan JanuariDesember 2020 untuk SP 1 (Grade A) sebanyak 366.414kg, SP 2 (Grade B) sebanyak 1.264kg, dan REST (Grade $C$ ) sebanyak $15.460,5 \mathrm{~kg}$. Sedangkan buah manggis yang tidak lolos sortir berdasarkan ketidaksesuaian ukuran (PK) sebanyak $8.197,5 \mathrm{~kg}$ dan kerusakan berdasarkan tingkat kematangan sebanyak $895,5 \mathrm{~kg}$. Total buah manggis yang lolos sortir sebanyak $383.138,5 \mathrm{~kg}$ atau $97,682 \%$ dan total buah manggis yang tidak lolos sortir yaitu sebanyak $9.093 \mathrm{~kg}$ atau $2,318 \%$. Secara keseluruhan buah manggis yang telah disortir pada bulan JanuariDesember 2020 sebanyak 392.231,5kg.

\section{Histogram}

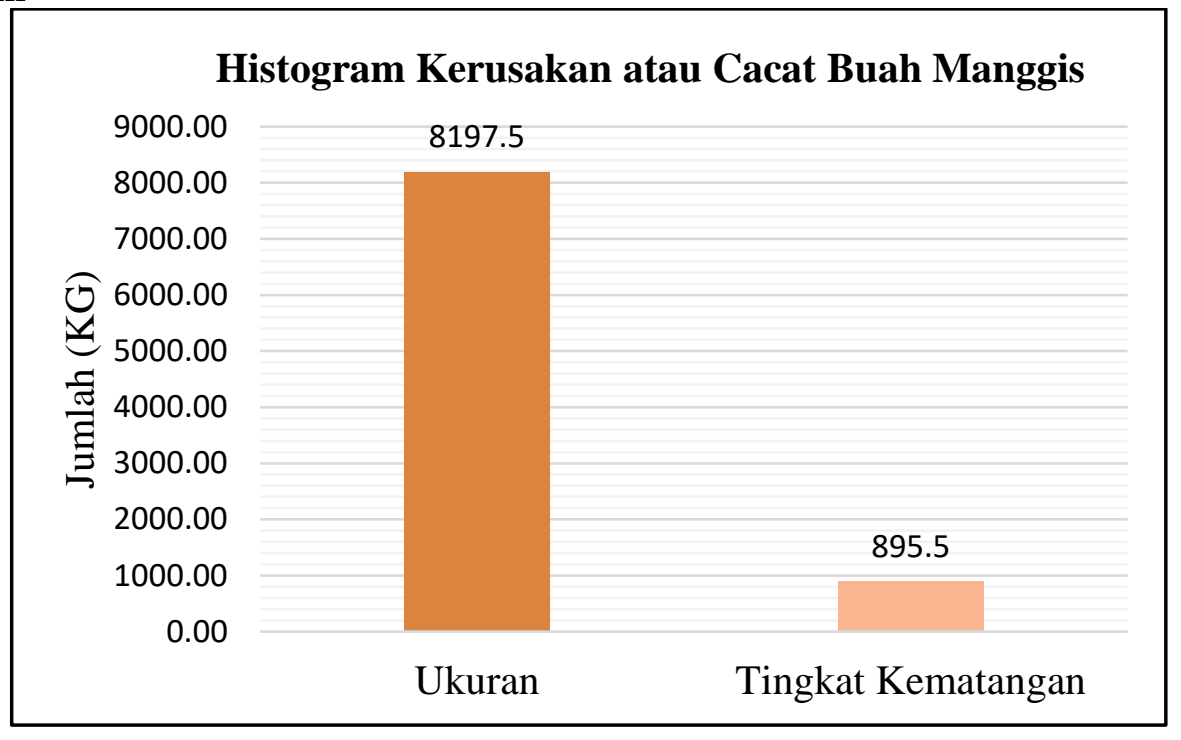

Gambar 2. Histogram

Gambar 2 menunjukkan bahwa ketidaksesuaian ukuran pada buah manggis sebanyak $8197.5 \mathrm{~kg}$ lebih tinggi dibandingkan pada ketidaksesuaian tingkat kematangan yang berjumlah $895.5 \mathrm{~kg}$. Hal tersebut berarti buah manggis yang tidak lolos sortir disebabkan oleh kerusakan yang paling tinggi terjadi yaitu pada ketidaksesuaian ukuran buah manggis.

\section{Peta Kendali $p$ ( $p$-chart)}

Peta kendali $\boldsymbol{p}$ disusun berdasarkan proporsi kerusakan, garis tengah (CL), batas kendali atas (UCL), batas kendali bawah (LCL) dengan rumus dan langkah-langkah sebagai berikut:

1. Menghitung proporsi kerusakan

Dimana:

$$
p_{i}=\frac{x_{i}}{n_{i}} \times 100 \%
$$

$p_{i}=$ proporsi buah manggis yang rusak pada grup/sampel 
$x_{i}=$ banyaknya buah manggis yang rusak pada grup/sampel

$n_{i}=$ jumlah buah manggis yang disortir pada grup/sampel

Adapun proporsi kerusakan atau cacat buah manggis untuk data ke-1, sebagai berikut:

$$
p_{1}=\frac{x_{1}}{n_{1}}=\frac{0}{1425}=0,000 \%
$$

Jadi, proporsi kerusakan untuk data ke-1 sebesar $0 \%$, begitu pula hasil proporsi kerusakan yang diperoleh untuk data ke-2 hingga data ke-41. Selanjutnya akan dihitung proporsi kerusakan untuk data kerusakan atau cacat pada data ke-42 dan ke-43, sebagai berikut:

$$
\begin{aligned}
& p_{42}=\frac{x_{42}}{n_{42}}=\frac{127.5}{3862,5}=3.301 \% \\
& p_{43}=\frac{x_{43}}{n_{43}}=\frac{75}{4065}=1.845 \%
\end{aligned}
$$

Berdasarkan data ke-42 diperoleh proporsi kerusakan sebesar $3.301 \%$ dan proporsi kerusakan buah manggis pada data ke-43 sebesar 1.845\%. Proporsi kerusakan data ke44 hingga data ke-100 dihitung menggunakan rumus yang sama.

2. Menghitung garis tengah (CL)

$$
C L=\bar{p}=\frac{\sum_{i=1}^{100} x_{i}}{\sum_{i=1}^{100} n_{i}}=\frac{9093}{392231.5}=2.318 \%
$$

Diperoleh nilai $C L$ atau garis tengah yang dapat disebut juga sebagai rata-rata dari kerusakan atau cacat pada buah manggis yaitu sebesar $2.318 \%$ atau 0.02318 .

3. Menghitung batas kendali atas (UCL)

Dimana:

$$
U C L=\bar{p}+3\left(\sqrt{\frac{\bar{p}(1-\bar{p})}{n}}\right)
$$

$\bar{p}=$ rata-rata kerusakan atau Center Line

$n=$ banyaknya grup/sampel

Dapat dihitung nilai batas kendali atas atau Upper Control Line (UCL), sebagai berikut:

$$
\begin{aligned}
U C L & =0.02318+3\left(\sqrt{\frac{0.02318(1-0.02318)}{100}}\right) \\
U C L & =0.02318+3\left(\sqrt{\frac{0.02264}{100}}\right) \\
U C L & =0.02318+3(0.01505) \\
U C L & =0.02318+0.04514 \\
U C L & =0.06832 \\
U C L & \approx 0.068
\end{aligned}
$$

Diperoleh nilai $\boldsymbol{U C L}$ atau batas kendali atas sebesar 0.068. Berdasarkan hasil batas kendali atas yang telah dihitung berarti jika proporsi kerusakan lebih dari $\mathbf{0 . 0 6 8}$, maka dapat diartikan kerusakan yang terjadi masih diluar batas kendali.

4. Menghitung batas kendali bawah (LCL)

$$
L C L=\bar{p}-3\left(\sqrt{\frac{\bar{p}(1-\bar{p})}{n}}\right)
$$

Dimana:

$\bar{p}=$ rata-rata kerusakan atau Center Line

$n=$ banyaknya grup/sampel

Dapat dihitung nilai batas kendali bawah atau Lower Control Line (LCL), sebagai berikut: 


$$
\begin{aligned}
& L C L=0.02318-3\left(\sqrt{\frac{0.02318(1-0.02318)}{100}}\right) \\
& L C L=0.02318-3\left(\sqrt{\frac{0.02264}{100}}\right) \\
& L C L=0.02318-3(0.01505) \\
& L C L=0.02318-0.04514 \\
& L C L=-0.02196 \\
& L C L \approx-0.022
\end{aligned}
$$

Diperoleh nilai $\boldsymbol{L C} \boldsymbol{L}=-\mathbf{0 . 0 2 2}$ atau $\boldsymbol{L C} \boldsymbol{L} \leq \mathbf{0}$ maka dapat ditentukan nilai $\boldsymbol{L C} \boldsymbol{L}=\mathbf{0}$.

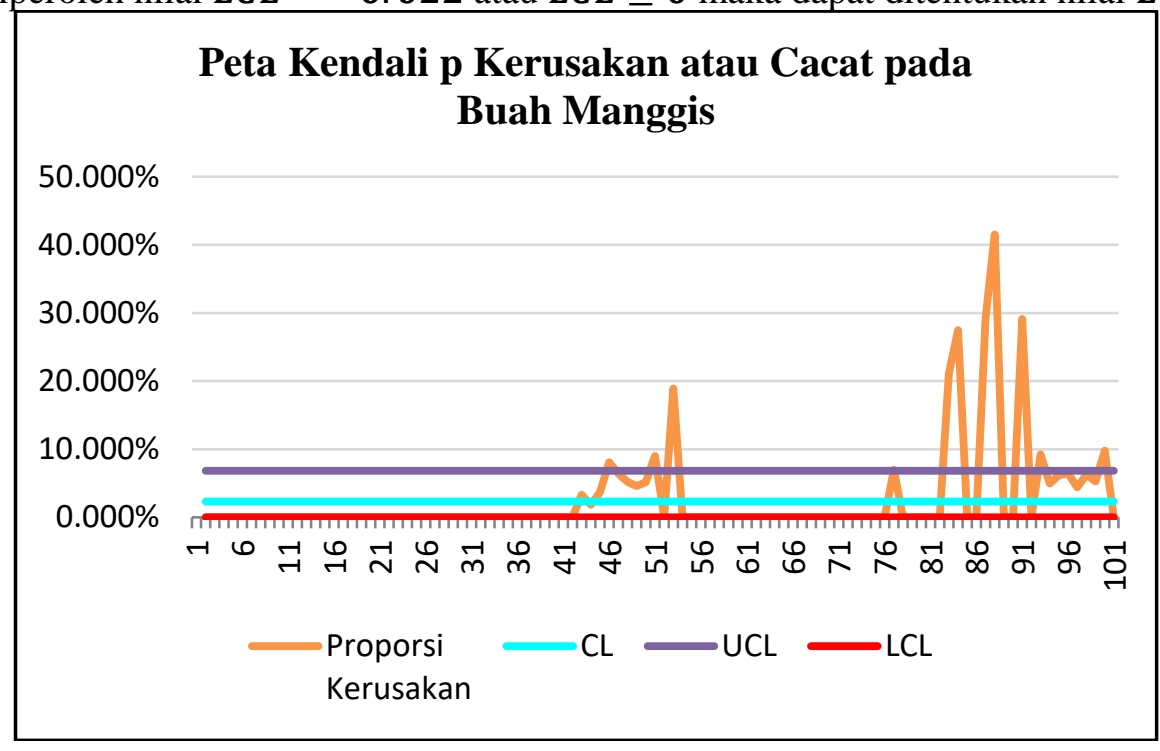

Gambar 3. Peta Kendali $p$

Berdasarkan Gambar 3 diketahui bahwa kerusakan yang terjadi berada diluar batas kendali atas. Hal tersebut ditunjukkan titik-titik ekstrim pada interval data $\mathbf{4 1}$ - 53 yang terjadi pada bulan Maret hingga April dan interval data 81- 101 terjadi pada bulan November hingga Desember dengan kerusakan yang paling tinggi terjadi pada data ke-87 mencapai $\mathbf{4 1 . 5 2 0} \%$.

Berdasarkan peta kendali $\boldsymbol{p}$ yang diperoleh dapat dilakukan analisis lebih lanjut mengenai penyebab kerusakan yang terjadi pada titik-titik ekstrim. Jika dilihat dari waktu ekspor yang dilakukan pada bulan November hingga Desember kerusakan yang terjadi sangat besar. Sedangkan pada bulan Maret hingga April kerusakan yang terjadi lebih kecil jika dibandingkan dengan kerusakan yang terjadi pada bulan November hingga Desember. Adapun untuk mengetahui faktor penyebab kerusakan atau cacat pada buah manggis dapat digunakan diagram sebab-akibat dimana dapat diketahui faktor penyebab kerusakan yang terjadi pada titiktitik ekstrim pada bulan Maret-April dan pada bulan November-Desember. 


\section{Diagram Pareto}

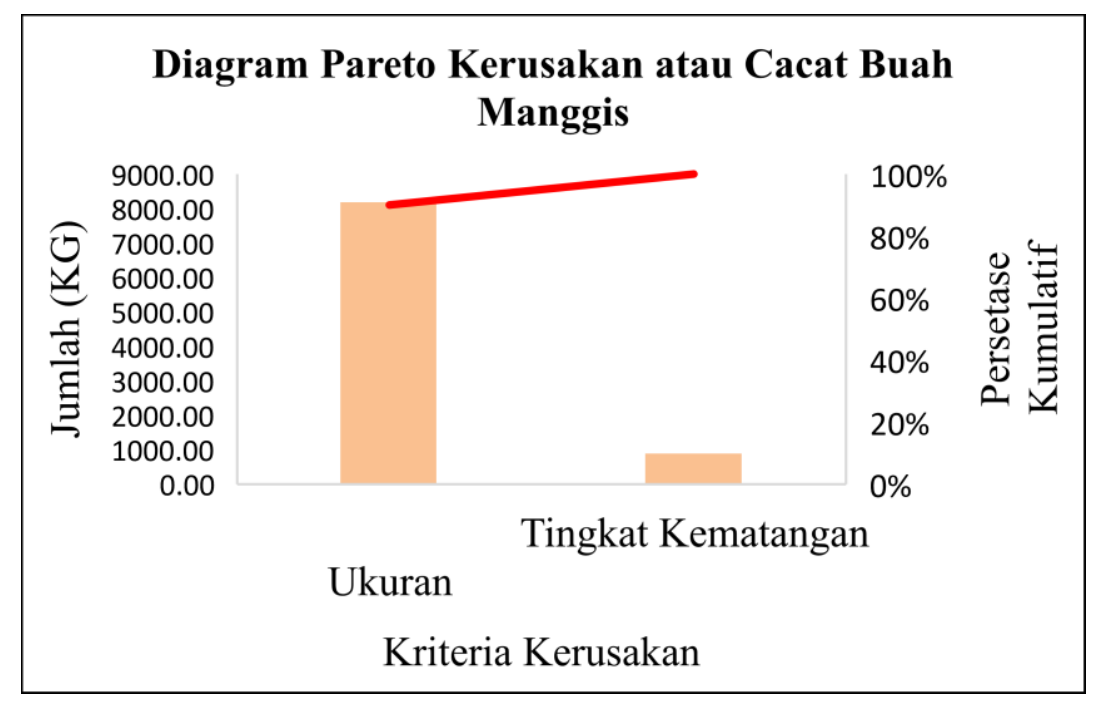

Gambar 4. Diagram Pareto

Berdasarkan prinsip pareto yang menyatakan bahwa $\mathbf{8 0} \%$ mutu suatu produk disebabkan oleh $\mathbf{2 0} \%$ penyebab kerusakan, sehingga dipilih jenis kerusakan dengan kumulatif mencapai $\mathbf{8 0} \%$ dengan asumsi bahwa $\mathbf{8 0} \%$ tersebut mewakili seluruh jenis kerusakan yang terjadi untuk meminimalkan kerusakan yang terjadi. Dapat dilihat pada Gambar 4 dengan persentase kumulatif dari ketidaksesuaian ukuran sebesar 90.152\%, maka ketidaksesuaian ukuran mewakili seluruh kerusakan yang terjadi untuk dilakukan perbaikan lebih awal. Hal tersebut berarti dengan memperbaiki atau meminimalkan kerusakan pada ketidaksesuaian ukuran, maka kerusakan yang terjadi pada buah manggis berada diangka minimum. Adapun ketidaksesuaian ukuran pada buah manggis menjadi kerusakan yang paling dominan dari 2 jenis kerusakan yang terjadi.

\section{Diagram Sebar (Scatter Diagram)}

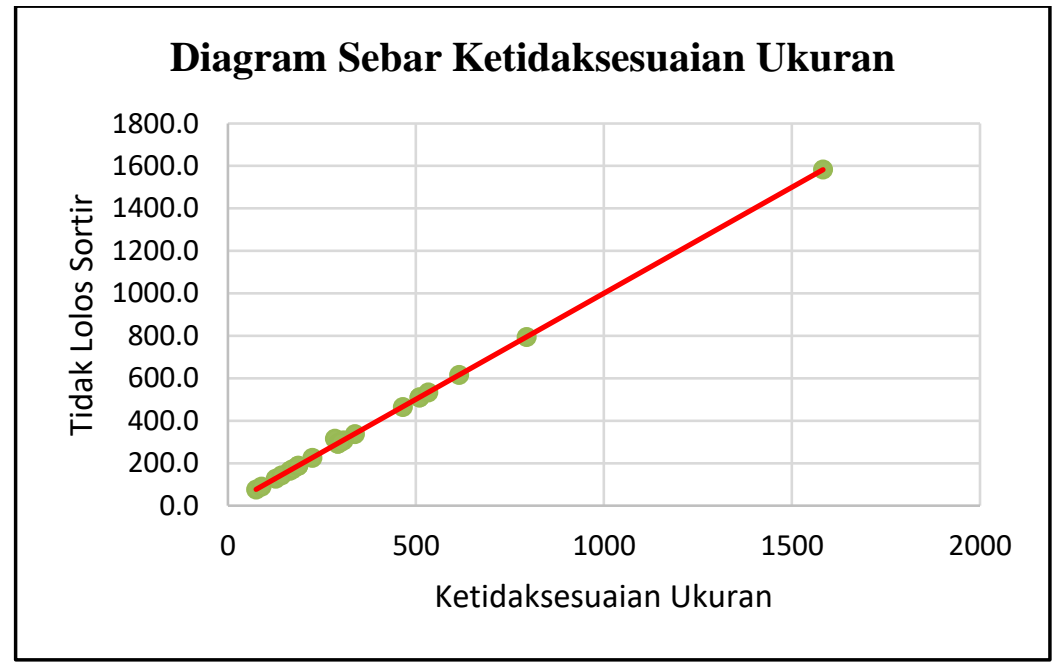

Gambar 5. Diagram Sebar Ketidaksesuaian Ukuran

Berdasarkan perhitungan sebelumnya diperoleh korelasi sebesar 0.934, jika dilihat pada tabel korelasi dimana korelasi yang ada pada interval 0.80-1.00 menunjukkan bahwa kuat hubungan yang terjadi sangat kuat diantara dua variabel. Hal ini berarti bahwa hubungan antara kerusakan yang terjadi berdasarkan ketidaksesuaian ukuran memiliki dampak yang sangat kuat dan signifikan terhadap buah manggis yang tidak lolos sortir. Gambar 5 menunjukkan korelasi 
yang bernilai positif dimana semakin meningkatnya kerusakan pada ketidaksesuaian ukuran maka semakin meningkat pula buah manggis yang tidak lolos sortir.

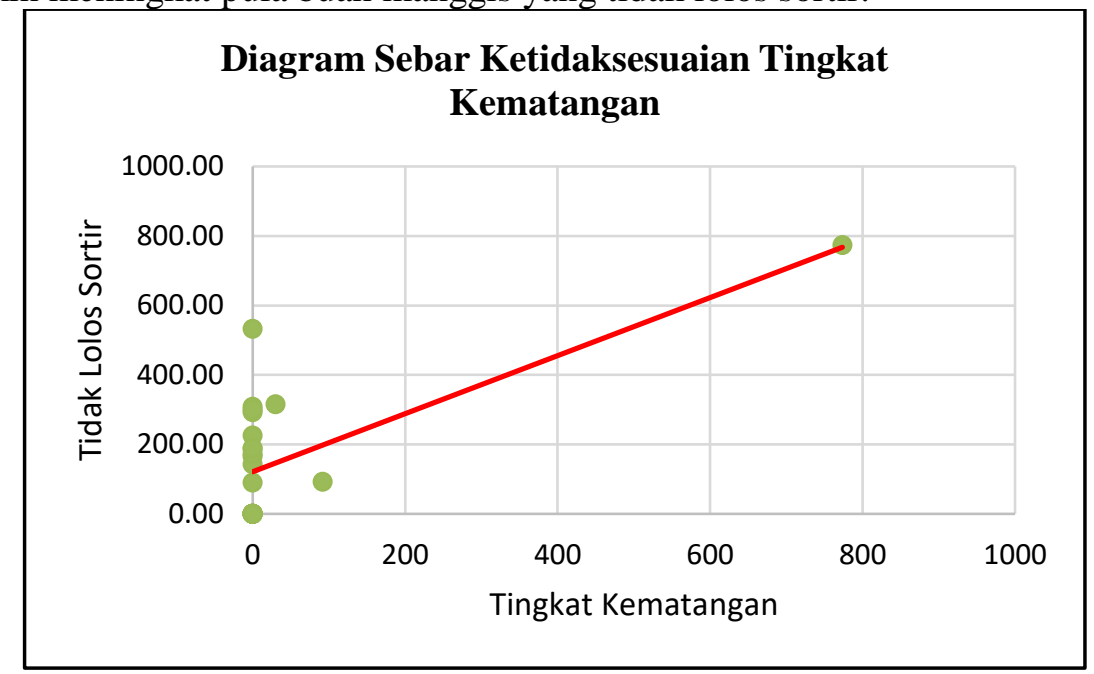

Gambar 6. Diagram Sebar Ketidaksesuaian Tingkat Kematangan

Berdasarkan perhitungan sebelumnya diperoleh korelasi sebesar $\mathbf{0 . 3 0 5}$, jika dilihat pada tabel korelasi dimana korelasi yang berada pada interval $0.200-0.399$ menunjukkan bahwa kuat hubungan yang terjadi rendah diantara dua variabel. Hal ini berarti bahwa hubungan antara kerusakan yang terjadi berdasarkan ketidaksesuaian tingkat kematangan memiliki dampak yang rendah dan tidak signifikan terhadap buah manggis yang tidak lolos sortir. Gambar 6 menunjukkan korelasi yang bernilai positif dimana semakin meningkatnya kerusakan pada ketidaksesuaian ukuran maka semakin meningkat pula buah manggis yang tidak lolos sortir.

\section{Diagram Sebab-Akibat (Fishbone Diagram)}

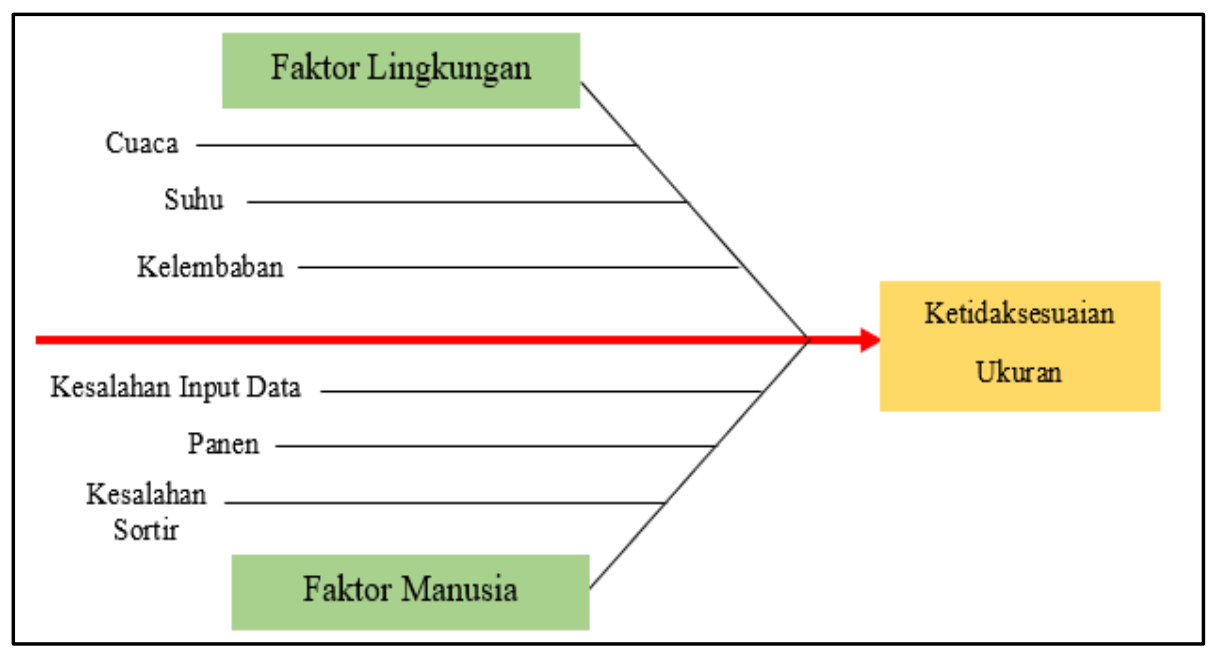

Gambar 7. Diagram Sebab-Akibat Keidaksesuaian Ukuran

Ketidaksesuaian ukuran dengan persentase kerusakan sebesar $\mathbf{9 0 . 1 5 2 \% ~ d e n g a n ~ h u b u n g a n ~}$ terhadap buah yang tidak lolos sortir sangat kuat yang ditunjukkan dari nilai korelasinya sebesar 0.934 yang disebabkan oleh beberapa faktor yang mempengaruhi kerusakannya, antara lain:

1. Faktor Lingkungan

Cuaca, iklim, suhu dan kelembaban udara yang berubah-ubah dapat menyebabkan buah manggis tumbuh tidak sempurna. Ditemukan buah manggis dengan ukuran yang berbeda-beda mulai dari sangat kecil hingga besar dan beberapa tidak memenuhi standar yang telah ditetapkan oleh PT. X 
2. Faktor Manusia

Penyortiran yang dilakukan secara manual, jika pegawai sudah mengalami kelelahan dan penyortiran dilakukan pada malam hari ditemukan buah manggis yang seharusnya lolos sortir menjadi tidak lolos sortir begitu pun sebaliknya. Buah manggis yang terlalu awal untuk di panen, sehingga ditemukan buah manggis yang belum memenuhi ukuran yang cukup untuk di panen. Adapun kesalahan pada saat penyimpanan data hasil penyortiran berdasarkan ketidaksesuaian ukuran.

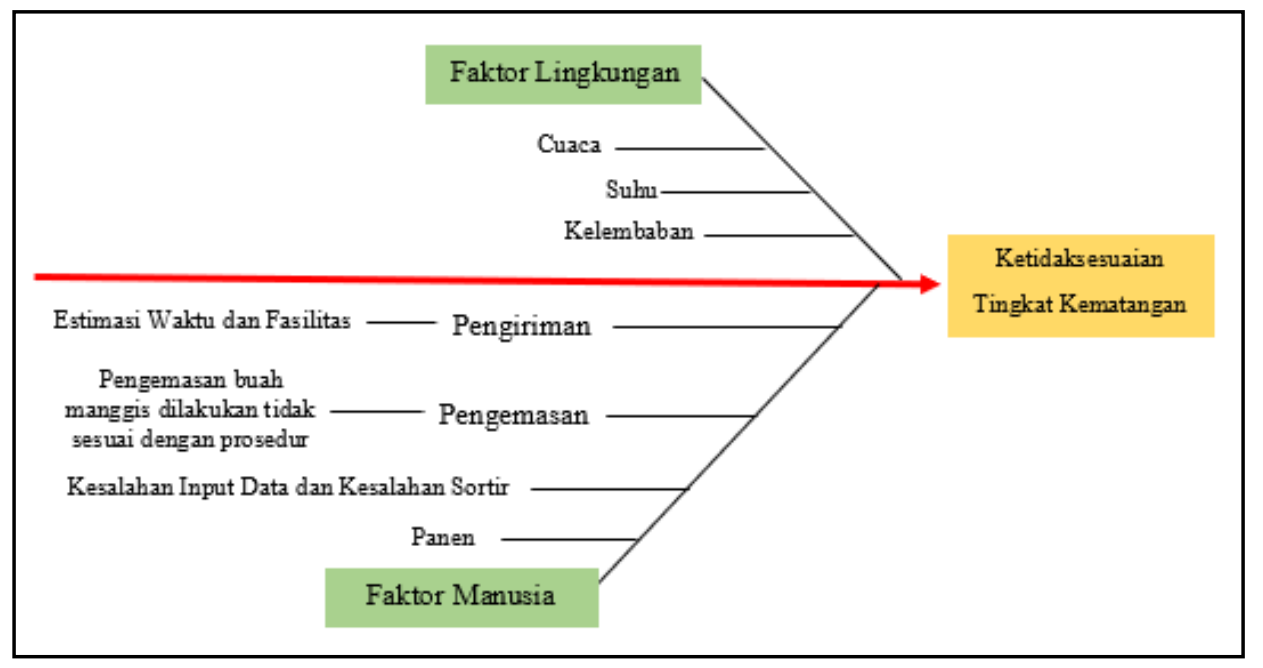

Gambar 8. Diagram Sebab-Akibat Ketidaksesuaian Tingkat Kematangan

Ketidaksesuaian tingkat kematangan buah manggis memiliki persentase kerusakan sebesar $9.848 \%$ dengan korelasi yang rendah sebesar 0.305 hubungan yang terjadi terhadap buah yang tidak lolos sortir tidak berdampak signifikan. Adapun faktor penyebab ketidaksesuaian tingkat kematangan antara lain, sebagai berikut:

a. Faktor Lingkungan

Cuaca, iklim, suhu, dan kelembaban udara yang berubah-ubah menyebabkan kematangan buah manggis tidak merata yang dapat dilihat dari warna pada buah manggis yang tidak merata. Pada tahap penyortiran ditemukan buah manggis dari yang belum matang dengan warna hijau dan buah yang sudah tidak layak konsumsi atau terlalu matang sehingga tidak memenuhi standar mutu yang telah ditetapkan oleh PT. X.

b. Faktor Manusia

Buah manggis akan mengalami kerusakan jika pengemasan tidak dilakukan dengan baik. Sebagai akibatnya akan menyebabkan buah terbentur saat pengiriman, udara masuk, dan suhu yang tidak sesuai saat penyimpanan. Karena hal tersebut, buah manggis akan mengalami proses kematangan yang cepat bahkan hingga buah manggis tidak layak untuk dikonsumsi. Kerusakan terjadi apabila buah manggis yang diekspor melebihi waktu yang sebelumnya sudah diestimasi oleh PT. X dan suhu penyimpanan saat pengiriman melebihi suhu yang telah ditentukan yaitu 10$13^{\circ} \mathrm{C}$. Kerusakan atau cacat berdasarkan tingkat kematangan disebabkan pula oleh panen yang dilakukan oleh petani pada saat buah manggis belum matang maupun buah manggis yang sudah lebih awal matang saat di panen. Adapun kesalahan pada saat penyimpanan data hasil penyortiran berdasarkan ketidaksesuaian tingkat kematangan buah manggis.

\section{Kesimpulan}

Berdasarkan pembahasan dalam penelitian ini, peneliti menyimpulkan bahwa kerusakan yang terjadi masih berada diluar batas kendali dibeberapa interval dengan batas kendali atas sebesar 0.068 dengan kerusakan yang paling dominan terjadi pada ketidaksesuaian ukuran pada buah 
manggis. Hal tersebut ditunjukkan pula oleh korelasi yang menunjukkan hubungan yang sangat kuat dengan nilai korelasi sebesar 0.934 terhadap buah manggis yang tidak lolos sortir. Adapun penyebab kerusakan dari buah manggis secara umum disebabkan oleh faktor lingkungan dan faktor manusia.

\section{Acknowledge}

Terimakasih diucapkan kepada Staf Produksi Eksportir PT. X yang telah meluangkan waktu untuk proses wawancara. Juga kepada Ibu Dr. Yani Ramdani, Dra., M.Pd dan Ibu Yurika Permanasari, S.Si., M.Kom yang telah membantu dan membimbing selama proses penelitian berlangsung dan pihak-pihak lain yang berkaitan dalam membantu dan memberi masukkan dalam penelitian ini.

\section{Daftar Pustaka}

[1] A. Syauqi, D. Dadang, I. Harahap dan M. Indrawartmi, "Gamma irradiation against mealybug Dysmicoccus lepelleyi (Betrem) (Hemiptera: Psedococcidae) on mangosteen fruit (Garcinia mangostana L.) as a Quarantine Treatment," Radiation Physics and Chemistry, pp. $1-7,2020$.

[2] D. Darmawansyih, "Khasiat Buah Manggis Untuk Kehidupan," Jurnal Al Hikmah, pp. 6170, 2014.

[3] D. C. Montgomery, Introduction to Statistical Quality Control, New York: Wiley, 2013.

[4] A. Rakhmad, "Penerapan Statistical Quality Control (SQC) dalam Pengendalian Proses Produksi Batik menggunakan Chart Control P (Grafik Pengendali P)," dalam Universitas Islam Negeri Sunan Kalijaga , Yogyakarta, 2019.

[5] B. Neyestani, "Seven Basic Tools of Quality Control: The Appropriate Techniques for Solving Quality Problems in the Organizations," SSRN, pp. 1-10, 2017.

[6] S. Yusuf dan H. Ahyadi, "Peningkatan Kualitas Proses Assembly Line 1 Dengan Menggunakan Statistical Quality Control (SQC) Pada PT. X," Sainstech, pp. 11-18, 2019.

[7] Sudjana, Metoda Statistika, Bandung: Tarsito, 2013.

[8] E. Roflin dan F. E. Zulvia, Kupas Tuntas Analisis Korelasi, Pekalongan: PT. Nasya Expanding Management, 2021. 